\title{
Fungi Associated with Damage Observed on Branches of Juglans nigra in Indiana, Missouri, and Tennessee
}

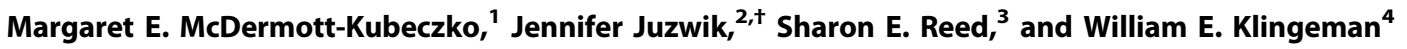 \\ ${ }^{1}$ College of Biological Sciences, University of Minnesota, Minneapolis, MN 55455, U.S.A. \\ ${ }^{2}$ Northern Research Station, USDA Forest Service, St. Paul, MN 55108, U.S.A. \\ ${ }^{3}$ Ontario Forest Research Institute, Ontario Ministry of Natural Resources, Sault Ste. Marie, ON, P6A 2E5 Canada \\ ${ }^{4}$ Department of Plant Sciences, University of Tennessee, Knoxville, TN 37996, U.S.A.
}

Accepted for publication 25 March 2020.

\begin{abstract}
Branch and stem cankers caused by Geosmithia morbida associated with mass attack by its primary insect vector (Pityophthorus juglandis) result in thousand cankers disease (TCD) on Juglans and Pterocarya species. Because other fungi and insects can cause visible damage to Juglans nigra, a baseline assessment was performed to document damage types present and to characterize fungi associated with each type. Two branches were collected from trees with visually healthy crowns in TCDfree locations (Indiana and Missouri) and two branches from trees with and without crown symptoms characteristic of TCD within the disease range in Tennessee. In most cases, one of the two branches was girdled at the base 3 to 4 months prior to harvest. Outer bark was peeled from branch subsamples,

observed damage characterized, and isolation of fungi from each damage type attempted. Three known pathogens of J. nigra were obtained from different damage types: G. morbida, in Tennessee only; Botryosphaeria dothidea, in Indiana and Tennessee; and Fusarium solani ( $=$ members of $F$. solani species complex), in all three states. The latter two fungi may exacerbate branch dieback and mortality of TCD-affected trees. These results will be of value to plant health specialists monitoring J. nigra in the field and laboratory diagnosticians processing survey samples.

Keywords: thousand cankers disease, walnut, Geosmithia morbida, Botryosphaeria dothidea, Fusarium solani
\end{abstract}

Thousand cankers disease (TCD), which affects walnut (Juglans) and wingnut (Pterocarya) species, occurs when cankers resulting from infection by Geosmithia morbida M. Kolarík, E. Freeland, C. Utley, \& N. Tisserat (Ascomycota: Hypocreales, Bionectriaceae) coalesce, leading to branch dieback. Tree mortality can, but does not always, result over several to many years (Griffin 2014; Hishinuma et al. 2016; Seybold et al. 2019; Tisserat et al. 2009). The association of G. morbida and the walnut twig beetle (WTB) (Pityophthorus juglandis [Blackman]; Coleoptera: Curculionidae, Scolytinae) with dead and dying trees was first described in Colorado as TCD in 2009 (Tisserat et al. 2009). The disease complex was subsequently found to be widespread across the western United States (Cranshaw 2011). Cankers occur most commonly around galleries of the WTB, and the fungus can be found sporulating in these galleries. The beetle is the primary vector of the pathogen.

${ }^{\dagger}$ Corresponding author: J. Juzwik; Jennifer.Juzwik@usda.gov

Funding: Partial funding for this research was provided by USDA Forest Service Forest Health Protection - Washington Office (special project) and the USDA National Institute of Food and Agriculture, Hatch project 1009630: TEN00495.

*The $\boldsymbol{e}$-Xtra logo stands for "electronic extra" and indicates that three supplementary tables are published online.

The author(s) declare no conflict of interest.

This article is in the public domain and not copyrightable. It may be freely reprinted with customary crediting of the source. The American Phytopathological Society, 2020.
Aggressive attacks on Juglans species by the WTB are followed by development of hundreds to thousands of cankers on branches and main stems of susceptible hosts. The WTB, G. morbida, and TCD-symptomatic Juglans nigra were first detected in the eastern United States in 2010 in Knoxville, Tennessee. As of mid-2019, the disease has since been reported from five other eastern states (Maryland, North Carolina, Ohio, Pennsylvania, and Virginia) (http://thousandcankers.com/general-information/tcd-locations/), as well as Italy (Montecchio and Faccoli 2014). Great concern was expressed over the potential of TCD to cause widespread mortality of the highly valuable eastern black walnut (J. nigra) within its native range (Newton et al. 2009), because this economically important tree species is highly susceptible to attack and colonization by $P$. juglandis (Hefty et al. 2016).

In addition to $G$. morbida and $P$. juglandis, other canker-causing fungi and insect pests colonize J. nigra and can cause branch decline, death, and occasionally whole-tree mortality. Carlson et al. (1993) isolated several Fusarium species from cankered J. nigra in young plantations during a survey in the midwestern United States. Previously, Fusarium solani had been shown to cause branch cankers on J. nigra in Kansas (Tisserat 1987). Botryosphaeria dothidea also has been associated with cankers on Juglans species, as well as many other woody perennial plants (Pijut 2005). In California and Tennessee, diverse fungal species were recovered from WTB galleries and margins of G. morbida cankers that occur within the inner phloem and cambium of TCD-symptomatic Juglans species (Gazis et al. 2018). Damage and discoloration can also be attributed to activity of scolytine beetles and other types of insects 
that utilize branches and main stems of $J$. nigra, including trees that have been artificially stressed by girdling (Reed et al. 2015). $G$. morbida has been reported on several of these scolytine and other weevil species that colonize Juglans spp. (Juzwik et al. 2015, 2016). To assist diagnosticians tasked to evaluate Juglans branch samples for presence of TCD complex members, baseline data are needed about common damage types encountered and the cooccurrence of fungi (particularly pathogens) associated with the diverse spots, lesions, cankers, stains, and insect damage that are found on J. nigra branches in the eastern states. To address this knowledge gap, an observational study was undertaken with specific objectives to (i) categorize the types of inner bark, cambium, and outer sapwood damage commonly associated with $J$. nigra branches on trees from three eastern states, including one (Tennessee) in which TCD is well-established; (ii) catalog the fungal species associated with various damage types, with an emphasis on detecting occurrence of known pathogens of J. nigra; and (iii) assess the influence of recent branch girdling stress, if any, on observed fungus or insectassociated damage.

\section{Study Trees and Walnut Branch Evaluation}

Study trees (J. nigra) used for categorizing typical observed damage were selected in four Indiana and two Missouri cities where TCD is not known to occur, as well as two suburbs of the greater Knoxville, Tennessee, area where TCD is well established (Table 1). Trees selected for this assessment were located along residential streets, in parks, in a cemetery, and on residential properties.

As a secondary evaluation, and because artificially stressed trees are known to increase the likelihood of insect attack and/or colonization (Reed et al. 2015) and occurrence or severity of fungal colonization, one of two sampled branches on each tree was flagged and girdled during late spring 2012 at most locations. Girdling injury was initiated by making two encircling cuts 5 to $10 \mathrm{~cm}$ apart into the outer sapwood using a pruning or rope saw, depending on branch accessibility from the ground. To control for within-tree girdling effects, no limbs were girdled on three trees in Indiana (negative controls) and three TCDsymptomatic trees in Tennessee (positive controls).

All branches were harvested between early September and mid October 2012. Prior to leaving a site, each branch was cut into multiple sections (28 to $30 \mathrm{~cm}$ long), transported to an initial processing site, and placed in plastic bags for storage at $4{ }^{\circ} \mathrm{C}$ (Indiana) or $-20^{\circ} \mathrm{C}$ (Tennessee and Missouri) until final sampling could be performed. Indiana branch samples were stored between 3 and 30 days before being further processed. The Missouri and Tennessee branch sections (frozen for less than 30 days) were thawed at $4{ }^{\circ} \mathrm{C}$ for 1 to 3 days before processing. Two sections from each branch of the Indiana and Tennessee study trees were selected for damage evaluation, whereas one section from each branch of the Missouri trees was selected.

In the laboratory, a curved-blade (5-cm-long) drawknife was used to remove portions of the outer bark on selected branch sections. Branch sections were observed for any signs of insect activity and life stage of any insects present. Details on insect damage, spots, stains, cankers, or lesions, or any mechanical damage, were recorded. Data recorded for each damage type included size $\left(\mathrm{cm}^{2}\right)$, color, margin characteristics, shape, and whether they occurred singly or were coalesced. To calculate the area of observed damage, a polypropylene sheet protector was laid over the branch section and the outline of the damaged area traced on the sheet using a fine-tip permanent marker. After filling in the areas with black marker, the sheets were electronically scanned and files saved as PDFs. The area of damage for each one was calculated using the measurement tool in Adobe Acrobat Professional (version 8.3.1). Representative samples of each damage type were photographed. Frequencies of occurrence for each type of damage on a branch section were determined for (i) girdled versus nongirdled branches from Indiana and Missouri and asymptomatic trees in Tennessee and (ii) nongirdled branches from TCD-symptomatic trees in Tennessee and three control trees in Indiana. One-way ANOVA was used to test for difference in occurrence of damage type between girdled and nongirdled treatments for each state (Forthofer and Lee 1995). Analyses were performed in $\mathrm{R}$ (version 3.3.3) using the dplyr (0.7.4) package (R-Core Team 2017).

The types of damage observed on branch sections from 17 Indiana and 16 Missouri trees included spots, stains, lesions or cankers, and discolored phloem tissue around metallic woodborer (Coleoptera: Buprestidae) or weevil (Coleoptera: Curculionidae) tunnels (Fig. 1; Table 2). All damage types were observed on branch sections from locations in two or more cities in Indiana and from three or more sites in Missouri (data not shown). The types of damage found on branch sections from 12 Tennessee trees included spots, stains, lesions or cankers, and discolored phloem observed around metallic woodborer or WTB tunnels and galleries (Fig. 1; Table 2).

In general, the girdling treatment had no significant effect on frequency of damage type occurrence for all three states. Specifically, disease-like symptoms (spots, lesions, or cankers) occurred with similar frequencies on both girdled and nongirdled branch sections from Indiana and Missouri $(P=0.724$ for Indiana; $P=$ 0.254 for Missouri); however, different, but inconsistent, patterns of borer damage were observed among girdled and nongirdled branches for these states. Two of three canker or lesion types occurred at similar frequencies on girdled and nongirdled branches in Tennessee $(P=0.684)$, whereas the third canker type was only observed on one branch section. Frequencies of WTB damage on a branch section basis were slightly higher for girdled treatments

\begin{tabular}{|c|c|c|c|c|}
\hline \multicolumn{5}{|c|}{$\begin{array}{c}\text { TABLE } 1 \\
\text { Number and characteristics of Juglans nigra study trees in Indiana, Missouri, and Tennessee }\end{array}$} \\
\hline State & Cities & Number of trees & Tree diameter (range in $\mathbf{~ c m}$ ) & TCD status $^{\mathrm{a}}$ \\
\hline Missouri & Columbia, Paris & 16 & $7.6-68.5$ & Not present \\
\hline Tennessee & Greater Knoxville area ${ }^{\mathrm{b}}$ & 9 & $33-63.5$ & No crown symptoms visible \\
\hline Tennessee & Greater Knoxville area & 3 & $<25$ & Visible crown symptoms \\
\hline
\end{tabular}

a Thousand cankers disease (TCD)-symptomatic J. nigra not reported to be present in Indiana or Missouri. In Tennessee, several J. nigra trees exhibiting and others not exhibiting crown symptoms typical of TCD were selected.

${ }^{\mathrm{b}}$ Asymptomatic trees were located in two sites in a southwestern Knoxville, Tennessee, suburb. Symptomatic trees were located in northern suburbs. 


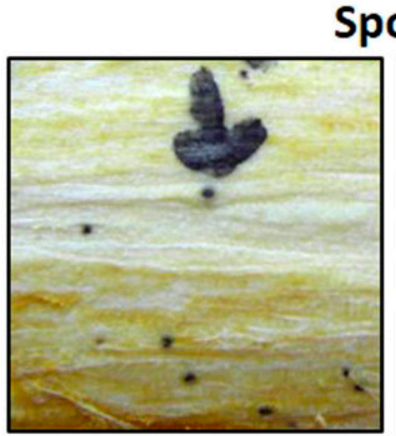

A

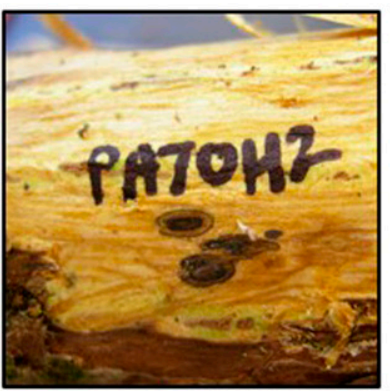

E

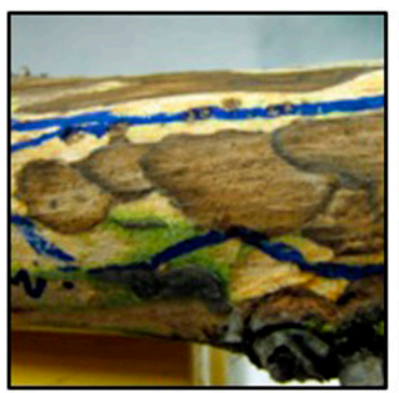

I

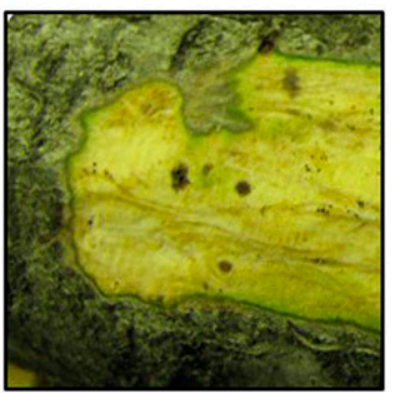

B

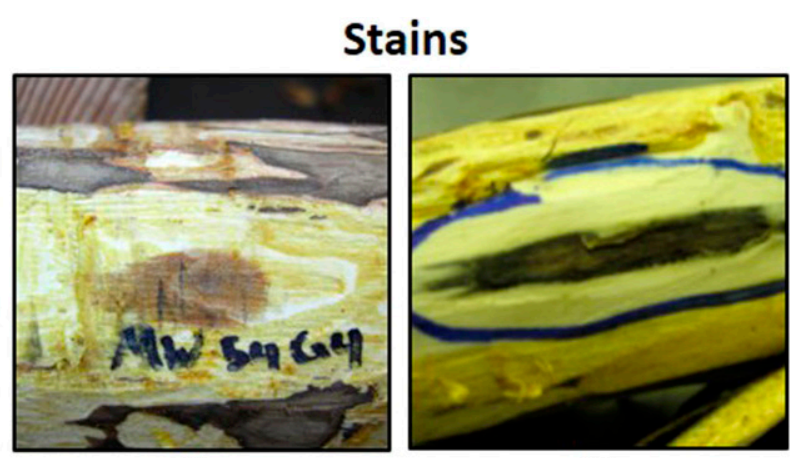

C

D

Lesions/Cankers

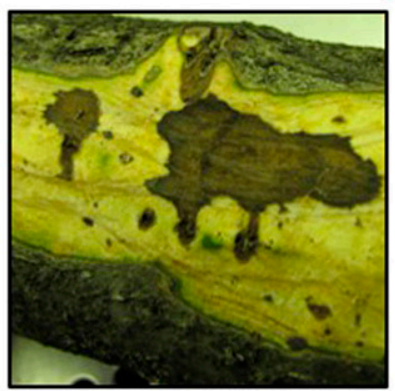

$\mathbf{F}$

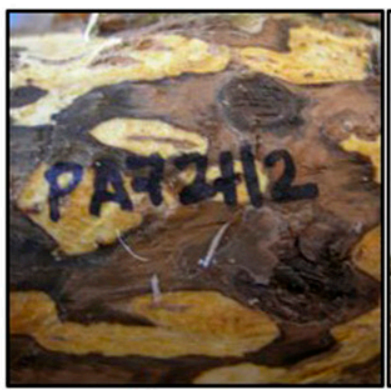

J

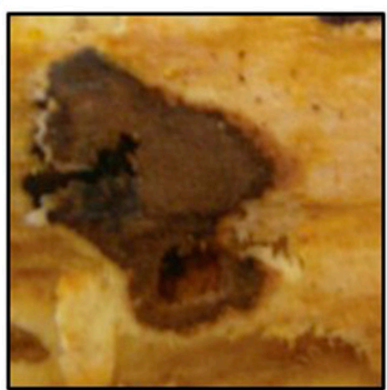

G

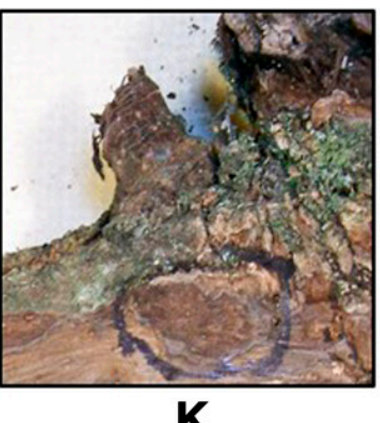

K

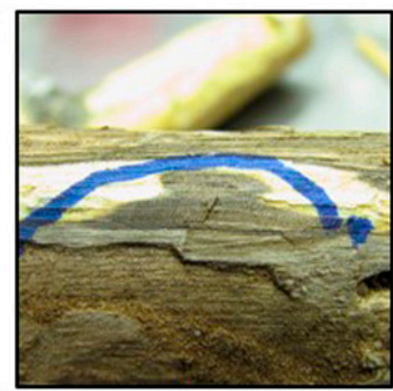

H

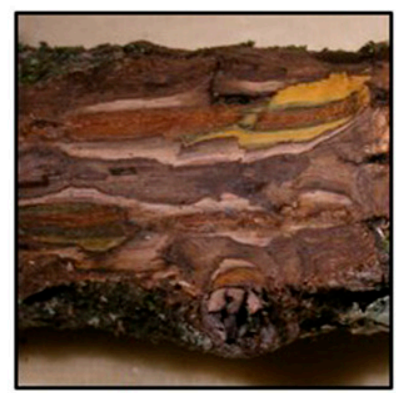

$\mathbf{L}$

Insect associated discoloration and damage

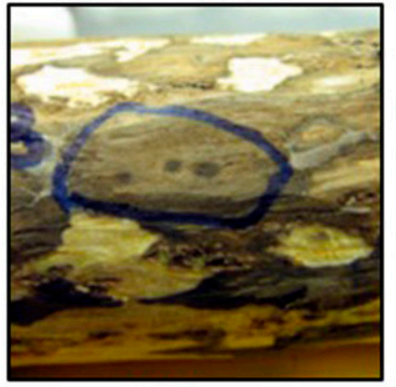

IW

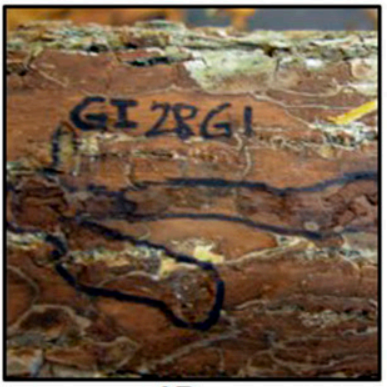

IB

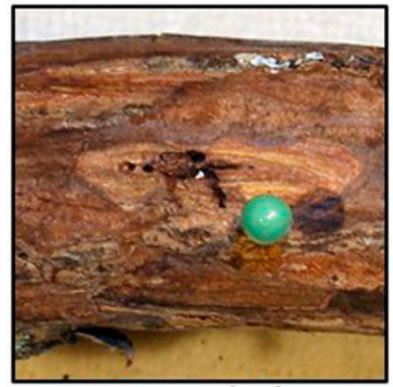

Pityophthorus juglandis (IPJ)

\section{FIGURE 1}

Types of damage observed on branch sections from Juglans nigra trees $(n=17)$ in four Indiana cities, J. nigra trees $(n=16)$ in two Missouri cities, and J. nigra trees $(n=12)$ in two suburbs of Knoxville, Tennessee, in September 2012. Damage types: $A$ and $B=$ spots; $C$ and $D=$ stains; $E$ to $L=l e s i o n s$ or canker-like areas; IW $=$ discolored phloem around weevil tunnels; IB = discolored phloem around metallic woodborer (Coleoptera: Buprestidae) tunnels; and IPJ = discolored phloem around Pityophthorus juglandis galleries. 
( $89 \%$ of sampled sections, $n=18$ ) from one branch from each of nine trees compared with nongirdled treatments (63\% of sampled sections, $n=18$ ) from one branch from each of nine trees. However, this difference was not significant $(P=0.61)$. Thus, the data for girdled and nongirdled treatments were combined for each state.

\section{Isolation of Fungi Associated with Damage Types Observed on Branches}

The bark on the branch sections described above was carefully shaved, and descriptions of damage observed in the phloem and the cambium-sapwood interface were recorded. After shaving and recording data for three to four branch sections, attempts were made to isolate fungi from the margins of representatives of each observed damage type observed on those sections (completed in the same day). Four inner bark and/or outer xylem tissue samples $\left(\leq 1 \mathrm{~cm}^{2}\right)$ were excised with a flame-sterilized scalpel blade and placed on each of two Petri dishes containing quarter-strength potato dextrose agar (PDA) amended with $100 \mathrm{mg} /$ liter of streptomycin sulfate and $100 \mathrm{mg} /$ liter of chloramphenicol (Tisserat et al. 2009). The plates were incubated in the dark at $23^{\circ} \mathrm{C}$ and checked twice weekly for resulting fungal growth. Observed isolates were subcultured on half-strength PDA and incubated under the same conditions described above until pure cultures were obtained by single-spore or hyphal-tip transfer. All isolates obtained were stored on half-strength PDA in glass vials at $4^{\circ} \mathrm{C}$ until identified. The original isolation plates were maintained in the dark at 23 to $25^{\circ} \mathrm{C}$ and approximately $45 \%$ relative humidity for 6 months and checked biweekly for morphological changes and sporulation.
For fungal isolate collections from each of the three states, representative isolates were grouped based on morphological characteristics such as colony color (top and reverse), growth rate, texture, and appearance of colony margins. When possible, tentative fungal identities were recorded based on microscopic examination of sporulating structures as well as colony morphological characters. However, final identifications reported here were based on DNA internal transcribed spacer (ITS) region sequences that were obtained for each isolate. The DNA extraction, amplification, and sequencing protocols used were as follows. A small amount of fungal material was removed for each isolate, placed in a $200-\mu \mathrm{l}$ strip tube with $200 \mu \mathrm{l}$ of CTAB lysis buffer $(1.4 \mathrm{M} \mathrm{NaCl}, 0.1 \mathrm{M}$ Tris- $\mathrm{HCl}, 20 \mathrm{mM}$ EDTA, and $2 \% \mathrm{CTAB}$ ), and stored frozen at $-20^{\circ} \mathrm{C}$ until further processed. The modified protocol utilizing a commercial DNA extraction kit (Gene Clean III, Qbiogene, http:// www.mpbio.com/) was used to obtain purified DNA for most of the isolates (per Lindner and Banik 2009). Polymerase chain reaction (PCR) amplification was performed in $15-\mu 1$ reaction mixtures containing $3 \mu \mathrm{l}$ of DNA template eluted in $50 \mu \mathrm{l}$ of water, $0.3 \mu \mathrm{l}$ of each forward and reverse primer (ITS1F and ITS4) (Gardes and Bruns 1993) at final concentration of $0.2 \mu \mathrm{M}$, dNTPs, each at $200 \mu \mathrm{M}$ final concentration, green GoTaq reaction buffer at $1 \times$ final concentration, and $0.075 \mu \mathrm{l}$ of GoTaq DNA polymerase (Promega, Madison, WI). Amplification reactions were temperature cycled in 96-well plates using a thermocycler (Bio-Rad, Hercules, CA) following conditions described by Lindner and Banik (2009). For the remaining isolates (approximately 25\%), a different commercially available kit (DNeasy Plant Mini Kit, Qiagen, Hilden, Germany)

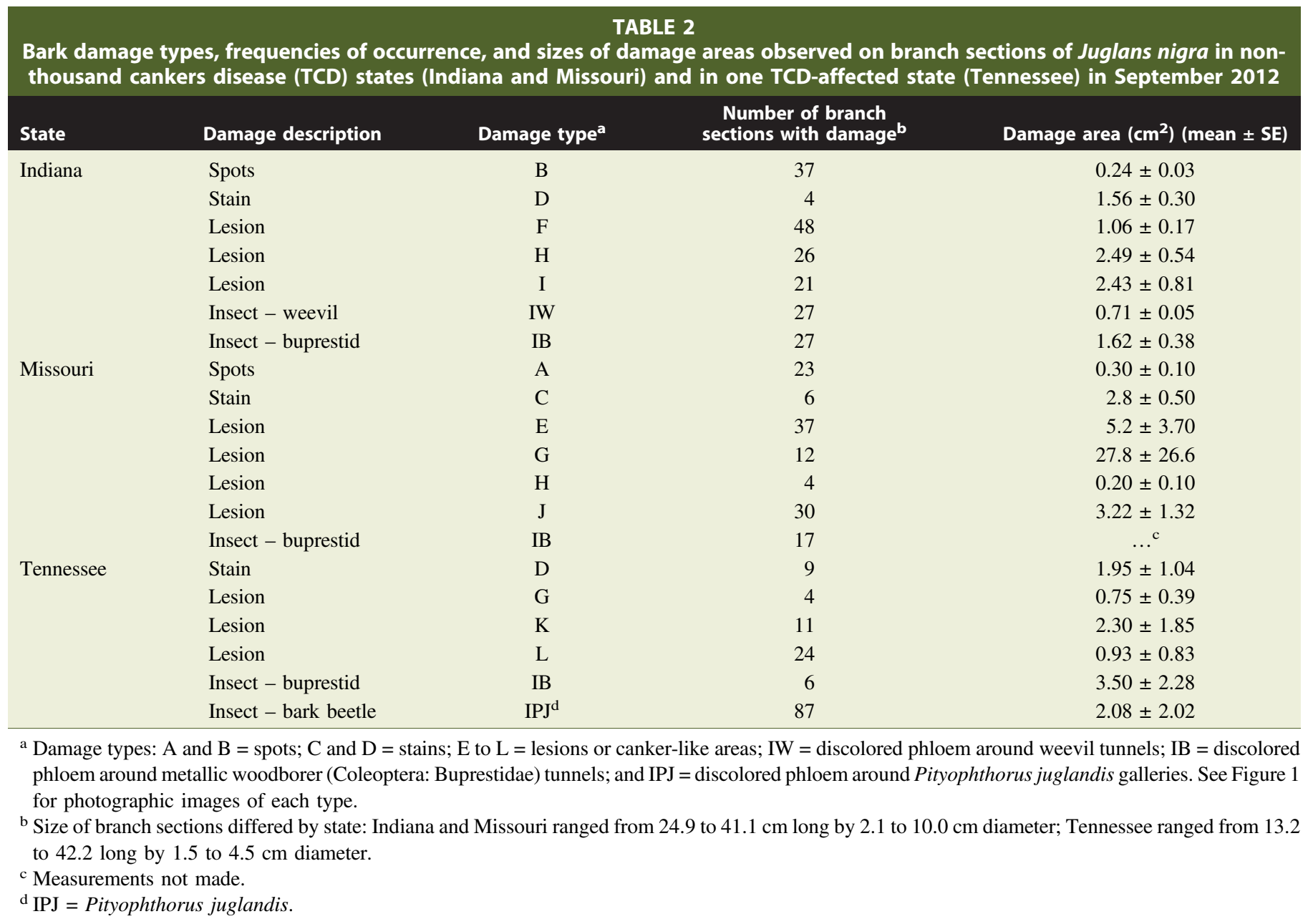


was used for DNA extraction and PCR per the manufacturer's instructions. In all cases, PCR products were visualized on $2 \%$ agarose gel stained with ethidium bromide $(0.5 \mu \mathrm{g} / \mathrm{ml})$ with ultraviolet light. The gel was immersed in Tris-borate-EDTA buffer and electrophoresis performed at $100 \mathrm{~V}$ for 15 min prior to visualization, to verify the presence of amplification products.

Sequencing reactions were performed on the cleaned PCR product, following the Big Dye terminator protocol (ABI Prism, Waltham, MA) with the ITS5 primer. For each sample, $1.8 \mu \mathrm{l}$ of molecular-grade water, $2.5 \mu \mathrm{l}$ of $5 \times$ buffer, $0.5 \mu \mathrm{l}$ of betaine, and $0.2 \mu$ l of ITS5 primer (10x) were combined with $7 \mu$ l of diluted DNA. Sequencing products were cleaned with magnetic beads (Agencourt CleanSEQ, Beckman-Coulter, Brea, CA) following the manufacturer's protocol. Direct-inject 96-well plates were analyzed ("read") using ABI 3730xl equipment at a commercial sequencing laboratory (Functional Biosciences, Madison, WI) to provide DNA sequences.

Fungal ITS sequences were viewed and edited using commercial software (4Peaks, available at nucleobytes.com). Alignment with sequences in the NCBI database was performed using BLAST and Clustal Omega. The closest matches to results that were returned from GenBank accessions were used to assign identity to the aligned sequences. All isolates were identified with $\geq 97 \%$ match for genus or $\geq 98 \%$ for species level identification.

\section{Fungi Isolated}

Fungal species reported here are restricted to the ones that can be cultured under the conditions described in the previous section. Fungi isolated from damaged areas on Indiana tree branch sections included 24 ascomycetes from 16 genera and one basidiomycete (Supplementary Table S1). Alternaria alternata, Diplodia seriata, Epicoccum nigrum, F. solani, and Penicillium spp. were the most frequently isolated fungi from branch sections $(>10)$ for all Indiana sites. Fungi isolated from the negative control tree sections represented seven of the 17 genera isolated from girdled branch sections, but the lack of diversity was attributed to the small number of control sections collected.

Fungi isolated from damaged areas on branch sections from Missouri trees included 10 ascomycete species representing eight genera (Supplementary Table S2). The most frequently isolated $(n=15)$ fungal taxon or species complex was $D$. seriata. Phaeoacremonium sp. Penicillium spp., and $F$. solani were isolated from four to six branches.

Fungi isolated from damage observed on branches from Tennessee trees included 64 ascomycetes representing 28 genera and six basidiomycetes representing four genera (Supplementary Table S3). Of these, 16 genera were isolated from branches obtained from both TCD-asymptomatic and -symptomatic trees. There were no genera identified in this study that were found only on symptomatic branch samples. In particular, G. morbida was isolated from symptomatic and asymptomatic branches from Tennessee. The highest frequencies of a fungal taxon or species complex present in branch segments $(\geq 9)$ were for the following species: A. alternata, B. dothidea, E. nigrum, $F$. solani, $G$. morbida, Paraconiothyrium sp., Penicillium spp., Pestalotiopsis spp., and Trichoderma harzianum. Gazis et al. (2018) reported that four species (T. harzianum complex, T. atroviride complex, Pestalotiopsis knightiae, and D. seriata, in descending order of prevalence) accounted for the majority of fungal isolates $(\geq 10)$ obtained from the margins of lesions typical of G. morbida cankers and WTB galleries on TCD-symptomatic J. nigra in Tennessee. T. harzianum is the only abundant taxon found in both our and the Gazis et al. (2018) studies. However, the isolates for our study were taken from a much broader range of symptomatic tissue types (i.e., spots, stains, lesions or cankers, and discolored phloem around woodborer tunnels or WTB galleries) than were the isolates from the Gazis et al. (2018) study.

\section{Fungi Obtained and Categorized by Lifestyle}

Fungi isolated from damaged areas on the branch sections were categorized by putative ecological lifestyle (= guild) (Nguyen et al. 2016). The majority of the isolated fungi were considered to be saprotrophic or plurivorous (e.g., Aspergillus and Penicillium species). The remaining fungi that were identified were classified as known or putative plant pathogens, entomopathogens, fungal parasites, and sapstain fungi; however, fungi known to be pathogenic on woody species, particularly on J. nigra, were a primary focus of our study (see next section).

Three entomopathogenic fungi were isolated from the branches, including Isaria farinosa in Indiana, Purpureocillium lilacinum in Missouri, and Fusarium larvarum in Tennessee, yet none of these species are known to be pathogenic to the WTB (Castillo Lopez et al. 2014; Teetor-Barsch and Roberts 1983; Zimmermann 2008). Trichoderma species, including T. harzianum, are potential fungal parasites (Elad et al. 1982; Gazis et al. 2018), and T. harzianum was isolated from branches in Indiana and Tennessee. One stain fungus, Cladosporium cladosporioides, which was isolated from cankerlike damage on branches from Tennessee, has also been detected in WTB galleries within walnut branch selections collected in California (OTU-58) (Gazis et al. 2018).

\section{Woody Plant Pathogens Isolated}

Five species of fungi isolated were categorized as pathogens of woody plants, and three fungal species (B. dothidea, F. solani, and G. morbida) are known pathogens of walnut (Fig. 2). Representative sequences of $F$. solani obtained from this study were deposited in GenBank (accession numbers MH973589, MH973590, and MH973591). Representative sequences of B. dothidea obtained from Indiana and Tennessee also were deposited in GenBank (accession numbers MH973592 and MH973593).

Biscogniauxia atropunctata was isolated from $P$. juglandisassociated damage on one branch in Tennessee. This species causes dieback of stressed oaks and has been reported from a number of host plant species, but it was not previously found on Juglans (Sinclair and Lyon 2005). For the known Juglans pathogens, $B$. dothidea was commonly isolated from canker-like damage (types $\mathrm{G}, \mathrm{K}$, and L) and from discolored xylem associated with insect tunnels or galleries of metallic woodborers and WTB, respectively, in Tennessee (as depicted in Figure 1).

"Botryosphaeria" obtusa (anamorph D. seriata) was isolated from a number of branch sections (Phillips et al. 2007). D. seriata is a cosmopolitan, plurivorous fungus (Phillips et al. 2013). Pathogenicity of this species on woody perennial hosts appears to differ greatly within species of host genera (Phillips et al. 2012). Ability of this species to cause disease in eastern black walnut is not known.

B. dothidea is an opportunistic pathogen associated with cankers and branch dieback of many woody perennial plants, including Juglans species (Mehl et al. 2013; Pijut 2005). Disease development is favored by hosts under physiological stress and may appear as black cankers in the crotches and limbs of the host, or occasionally as sudden wilt of foliage and twig necrosis. Botryosphaeria species have been previously isolated along with G. morbida from TCD-confirmed trees in California (Bostock 2014) and Tennessee (Gazis et al. 2018). Juglans species have shown varying resistance to $B$. dothidea, although all host species, including $J$. nigra, produced cankers following artificial inoculation (Smith 1934). 

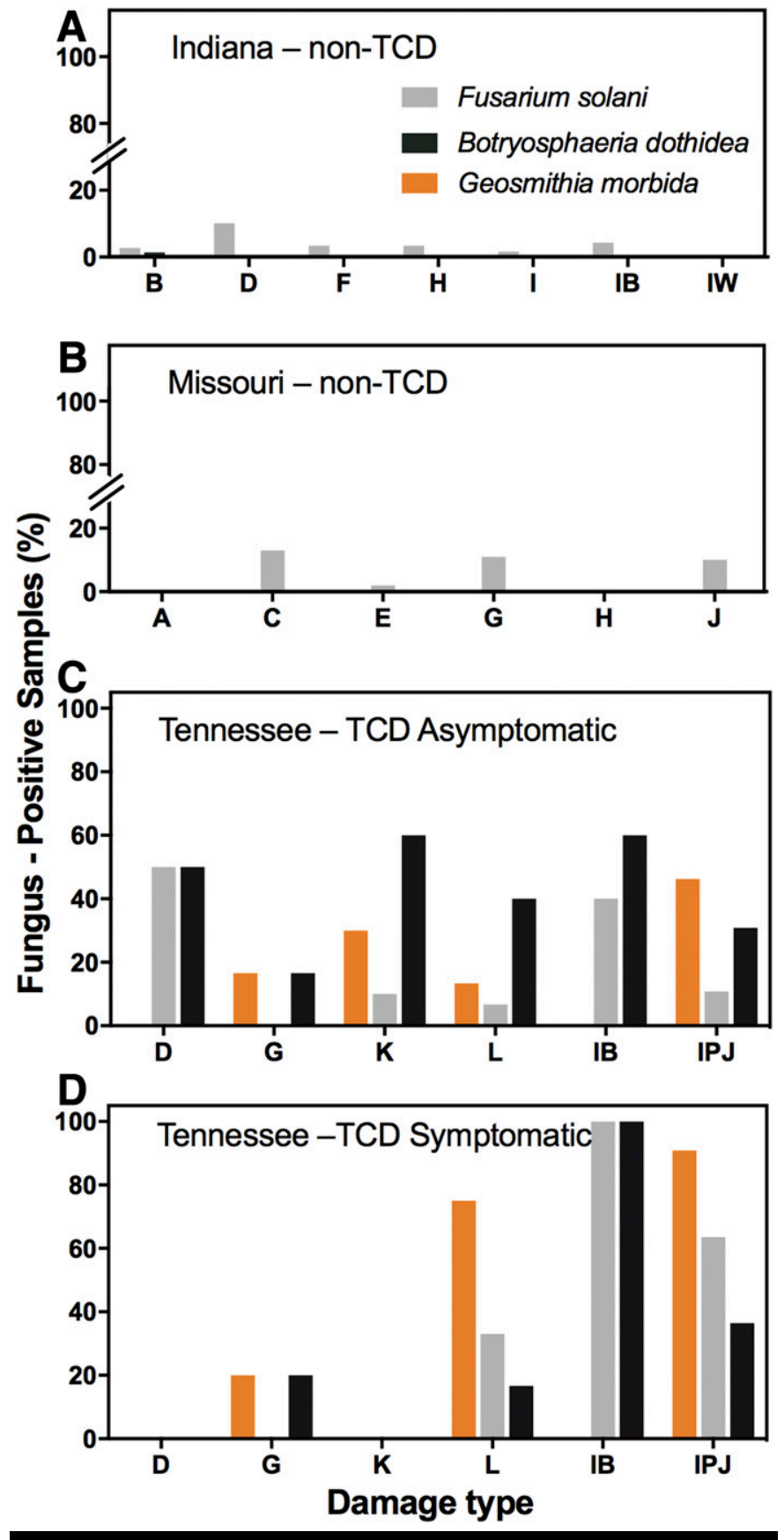

FIGURE 2

Frequencies of known plant pathogenic fungi of Juglans spp. isolated from branch sections of Juglans nigra in Indiana, Missouri, and Tennessee, 2012. For Indiana (A), two sections from two branches of 14 trees were evaluated. For Missouri (B), one section from two branches of 16 trees were evaluated. For Tennessee thousand cankers disease (TCD)-asymptomatic trees (C), two sections from two branches of nine trees were evaluated. For Tennessee TCDsymptomatic trees (D), two sections from two branches of three trees were assessed. Damage types: $A$ and $B=$ spots; $C$ and $D=$ stains; $E$ to $L=$ lesions or canker-like areas; IW = discolored phloem around weevil tunnels; IB = discolored phloem around metallic woodborer (Coleoptera: Buprestidae) tunnels; and IPJ = discolored phloem around Pityophthorus juglandis galleries .

F. solani was isolated from walnut branch sections in each of the three states, but isolates were not identified to phylogenetic species within the $F$. solani species complex (FSSC). In Tennessee, $F$. solani was isolated from several types of damage on both TCD- symptomatic and -asymptomatic trees. Several Fusarium species are known to cause cankers on J. nigra in the central United States (Carlson et al. 1993; Farr and Rossman 2017), but $F$. solani is the most common (Tisserat 1987). Infection can lead to formation of dark, elongated cankers that break the bark on J. nigra (Sinclair and Lyon 2005). Occurrence of such cankers on the lower stem may girdle and subsequently kill the tree. Cankers may also occur on the main stem and on branches in the crown of the tree. Leaf wilt and subsequent branch dieback may result. Epicormic shoots are often produced below a canker or at the base of fungus-girdled trees. The fungus has been isolated from trunk cankers of $J$. nigra main stems exhibiting advanced symptoms of TCD, but $F$. solan $i$ was considered of minor importance in TCD development in Colorado (Tisserat et al. 2009). In a more recent study in Colorado, no differences were found in size of bark cankers associated with inoculations of $F$. solani (phylogenetic species 6 of FSSC), when compared with inoculations using sterile agar controls on branches of walnut saplings (Sitz et al. 2017). In an earlier report from Italy, a distinct haplotype of FSSC (phylogenetic species 25) was associated with early TCD development on J. nigra (Montecchio et al. 2015).

The TCD pathogen, G. morbida, was only isolated from Tennessee trees. The fungus was obtained from all three types of cankers observed on Tennessee branches and from WTB tunnels and galleries. Frequency of G. morbida presence in branch sections of this study was considered "high" ( $>9$ sections with the fungus), but Gazis et al. (2018) considered "low" recovery to be $<10 \mathrm{G}$. morbida isolates obtained from Tennessee branch samples. Although G. morbida is considered to be a weak pathogen (Ploetz et al. 2013), the numerous inoculation points created by activity of the WTB can result in numerous small cankers that can coalesce to girdle a branch (Tisserat et al. 2009). Diagnosis of TCD has traditionally been based on detection of $P$. juglandis in branches paired with isolation of G. morbida from cankered tissue. However, in the eastern United States, isolation of G. morbida from suspect walnut branch tissues has been challenging for some laboratories in which traditional culture-based techniques often yielded inconsistent or null (and potentially false negative) results (Oren et al. 2018). This can lead to delays (weeks to months) in official diagnostic reporting of the fungus. Documenting the variation of the types of cankers from which the pathogen was isolated (Fig. 2) as well as the other common damage types observed that did not yield G. morbida will be of value to laboratory diagnosticians processing suspected TCD samples, especially in states not yet known to have the disease. In addition, recent development of an accurate and rapid molecular assay will improve laboratory detection of the pathogen in phloem and cambium tissues (Oren et al. 2018).

\section{Summary and Conclusions}

In our assessment of spots, lesions or cankers, and discoloration associated with insect colonization found in the inner bark, cambium, and outer sapwood of J. nigra, the fungal species isolated represent a portion of the fungal community on the host both within and outside of TCD-affected geographical locations. Types of damage observed in the inner bark and outer sapwood were characterized, and fungal isolations were attempted from the damaged areas. It is clear that in locations where TCD occurs, other damage types besides typical G. morbida cankers and WTB galleries were present, and the TCD pathogen was isolated from three of these other damage types. These other canker types were (i) roughly circular in shape, even brown tone in color; (ii) elliptical to elongated in shape, one- or two-tone brown in color; and (iii) long and narrow in shape, dark brown to black in color. In contrast, a typical G. morbida canker appears roughly circular in shape and 
two-tone brown in color (Seybold et al. 2013). These results will be useful to diagnostic laboratories processing suspected TCD samples. In addition, $F$. solani and $B$. dothidea were isolated from damage on branches in two and three, respectively, of the states in this study. Both pathogens could potentially contribute to branch dieback in TCD-symptomatic J. nigra. Furthermore, these pathogens may cause crown decline similar to TCD on trees that are not colonized by $P$. juglandis and G. morbida. Findings will be of value to forest health specialists and plant health survey technicians who monitor walnut tree health in urban and rural areas. Lastly, our results demonstrate the need for study of potential confounding roles of $B$. dothidea and $F$. solani in causing branch dieback and contributing to death of trees that are also colonized by $P$. juglandis and G. morbida in the eastern United States. Determination of the relative virulence of each of these pathogens on the same J. nigra in an eastern state would be of particular interest.

\section{Acknowledgments}

Collection and shipment of all walnut branches from Tennessee to Minnesota was in compliance with conditions of USDA APHIS Permit No. P526-12-03869. Field assistance from Matt Paschen in Indiana and Alicia Bray in Tennessee is gratefully acknowledged. Securing locations for field sites in Missouri was facilitated by Simeon Wright and Brett Brian, in Tennessee by Phil Flanagan, and in Indiana by Lenny Farley. Laboratory assistance provided by Lijun Duan and Antoine Tireau in Minnesota and Will Sammons in Missouri was also greatly appreciated.

\section{Literature Cited}

Bostock, R. 2014. Thousand cankers disease of walnut. Current Issues in Invasive/Emerging Pests and Diseases Workshop. February 5, 2014. University of California Davis, Davis, CA. https:/ccuh.ucdavis.edu/sites/g/files/ dgvnsk1376/files/inline-files/5\%20TCD\%20Bostock\%202-5-14.pdf

Carlson, J. C., Mielke, M. E., Appleby, J. E., Hatcher, R., Hayes, E. M., and Luley, C. J. 1993. Survey of black walnut canker in plantations in five central states. North. J. Appl. For. 10:10-13.

Castillo Lopez, D., Zhu-Salzman, K., Ek-Ramos, M. J., and Sword, G. A. 2014. The entomopathogenic fungal endophytes Purpureocillium lilacinum (formerly Paecilomyces lilacinus) and Beauveria bassiana negatively affect cotton aphid reproduction under both greenhouse ad field conditions. PLoS One 9:e102891.

Cranshaw, W. S. 2011. Recently recognized range extensions of the walnut twig beetle, Pityophthorus juglandis Blackman (Coleoptera: Curculionidae: Scolytinae) in the western United States. Coleopt. Bull. 65:48-49.

Elad, Y., Chet, I., and Henis, Y. 1982. Degradation of plant pathogenic fungi by Trichoderma harzianum. Can. J. Microbiol. 28:719-725.

Farr, D. F., and Rossman, A. Y. 2017. Fungal Databases, U.S. National Fungus Collections, ARS, USDA. https://nt.ars-grin.gov/fungaldatabases/.

Forthofer, R. N., and Lee, E. S. 1995. Introduction to Biostatistics: A Guide to Design, Analysis, and Discovery. Academic Press, New York, NY.

Gardes, M., and Bruns, T. D. 1993. ITS primers with enhanced specificity for basidiomycetes-Application to the identification of mycorrhizae and rusts. Mol. Ecol. 2:113-118.

Gazis, R., Poplawski, L., Klingeman, W., Boggess, S. L., Trigiano, R. N., Graves, A. D., Seybold, S. J., and Hadziabdic, D. 2018. Mycobiota associated with insect galleries in walnut with thousand cankers disease reveals a potential natural enemy against Geosmithia morbida. Fungal Biol. 122:241-253.

Griffin, G. J. 2014. Status of thousand cankers disease on eastern black walnut in the eastern United States at two locations over 3 years. For. Pathol. 45:203-214.

Hefty, A., Coggeshall, M. V., Aukema, B. H., Venette, R. C., and Seybold, S. J. 2016. Reproduction of walnut twig beetle in black walnut and butternut. HortTechnology 26:727-734.

Hishinuma, S. M., Dallara, P. L., Yaghmour, M. A., Zerillo, M. M., Parker, C. M., Roubtsova, T. V., Nguyen, T. L., Tisserat, N. A., Bostock, R. M., Flint, M. L., and Seybold, S. J. 2016. Wingnut (Juglandaceae) as a new generic host for Pityophthorus juglandis (Coleoptera: Curculionidae) and the thousand cankers disease pathogen, Geosmithia morbida (Ascomycota: Hypocreales). Can. Entomol. 148:83-91.

Juzwik, J., Banik, M., Reed, S., English, J., and Ginzel, M. 2015. Geosmithia morbida found on weevil species Stenomimus pallidus in Indiana. Plant Health Prog. 16:7-10.
Juzwik, J., McDermott-Kubeczko, M., Stewart, T., and Ginzel, M. 2016. First report of Geosmithia morbida on ambrosia beetles emerged from thousand cankers-diseased Juglans nigra in Ohio. Plant Dis. 100:1238.

Lindner, D. L., and Banik, M. T. 2009. Effects of cloning and root-tip size on observations of fungal ITS sequences from Picea glauca roots. Mycologia 101:157-165.

Mehl, J. W. M., Slippers, B., Roux, J., and Wingfield, M. J. 2013. Cankers and other diseases caused by the Botryosphaeriaceae. Pages 298-317 in: Infectious Forest Diseases. P. Gonthier and G. Nicolotti, eds. CAB International, Wallingford, U.K.

Montecchio, L., and Faccoli, M. 2014. First record of thousand cankers disease Geosmithia morbida and walnut twig beetle Pityophthorus juglandis on Juglans nigra in Europe. Plant Dis. 98:696.

Montecchio, L., Faccoli, M., Short, D. P. G., Fanchin, G., Geiser, D. M., and Kasson, M. T. 2015. First report of Fusarium solani phylogenetic species 25 associated with early stages of thousand cankers disease on Juglans nigra and Juglans regia in Italy. Plant Dis. 99:1183.

Newton, L., Fowler, G., Neeley, A., Schall, R., and Takeuchi, Y. 2009. Pathway Assessment: Geosmithia sp. and Pityophthorus juglandis Blackman Movement from the Western into the Eastern United States. USDA Animal and Plant Health Inspection Service, Raleigh, NC. https://agriculture.mo.gov/ plants/pdf/tc_pathwayanalysis.pdf.

Nguyen, N. H., Song, Z., Bates, S. B., Branco, S., Tedersoo, L., Menke, J., Schilling, J. S., and Kennedy, P. G. 2016. FUNGuild: An open annotation tool for parsing fungal community datasets by ecological guild. Fungal Ecol. 20: 241-248.

Oren, E., Klingeman, W. E., Gazis, R., Moulton, J., Lambdin, P., Coggeshall, M., Hulcr, J., Seybold, S. J., and Hadziabdic, D. 2018. A novel molecular toolkit for rapid detection of the pathogen and primary vector of thousand cankers disease. PLoS One 13:e0185087.

Phillips, A. J. L., Alves, A., Abdollahzaden, J., Slippers, B., Wingfield, M. J., Groenewald, J. Z., and Crous, P. W. 2013. The Botryosphaeriaceae: Genera and species known from culture. Stud. Mycol. 76:51-167.

Phillips, A. J. L., Crous, P. W., and Alves, A. 2007. Diplodia seriata, the anamorph of "Botryosphaeria" obtusa. Fungal Divers. 25:141-155.

Phillips, A. J. L., Lopes, J., Abdollahzadeh, J., Bobev, S., and Alves, A. 2012. Resolving the Diplodia complex on apple and other Rosaceae hosts. Persooonia 29:29-38.

Pijut, P. M. 2005. Diseases in Hardwood Tree Plantings. FNR-221. USDA Forest Service/Purdue University, West Lafayette, IN. https://www.extension. purdue.edu/extmedia/FNR/FNR-221.pdf.

Ploetz, R. C., Hulcr, J., Wingfield, M. J., and de Beer, Z. W. 2013. Destructive tree diseases associated with ambrosia and bark beetles: Black swan events in tree pathology? Plant Dis. 97:856-872.

R Core Team. 2017. R: A language and environment for statistical computing. R Foundation for Statistical Computing, Vienna, Austria. http://www.Rproject.org/

Reed, S. E., Juzwik, J., English, J. T., and Ginzel, M. D. 2015. Colonization of artificially stressed black walnut trees by ambrosia beetle, bark beetle, and other weevil species (Coleoptera: Curculionidae) in Indiana and Missouri. Environ. Entomol. 44:1455-1464.

Seybold, S., Haugen, D., and Graves, A. 2013. Thousand cankers disease. Pest Alert NA-PR-10. USDA Forest Service, Newtown Square, PA.

Seybold, S. J., Klingeman, W. E., III, Hishinuma, S. M., Coleman, T. W., and Graves, A. D. 2019. Status and impact of walnut twig beetle in urban forest, orchard, and native forest ecosystems. J. For. 117:152-163.

Sinclair, W. A., and Lyon, H. H. 2005. Diseases of Trees and Shrubs. Cornell University Press, Ithaca, NY.

Sitz, R. A., Luna, E. K., Caballero, J. I., Tisserat, N. A., Cranshaw, W. S., and Stewart, J. E. 2017. Virulence of genetically distinct Geosmithia morbida isolates to black walnut and their response to co-inoculation with Fusarium solani. Plant Dis. 101:116-120.

Smith, C. 1934. Inoculations showing the wide host range of Botryosphaeria ribis. J. Agric. Res. 49:467-476.

Teetor-Barsch, G. H., and Roberts, D. W. 1983. Entomogenous Fusarium species. Mycopathologia 84:3-16.

Tisserat, N. 1987. Stem canker of black walnut caused by Fusarium solani in Kansas. Plant Dis. 71:557.

Tisserat, N., Cranshaw, W., Leatherman, D., Utley, C., and Alexander, K. 2009. Black walnut mortality in Colorado caused by the walnut twig beetle and thousand cankers disease. Plant Health Prog. 10. doi: 10.1094/PHP-20090811-01-RS.

Zimmermann, G. 2008. The entomopathogenic fungi Isaria farinosa (formerly Paecilomyces farinosus) and the Isaria fumosorosea species complex (formerly Paecilomyces fumosoroseus): Biology, ecology and use in biological control. Biocontrol Sci. Technol. 18:865-901. 